\title{
The Culture of Indian Migration: A Theoretical and Empirical Analysis of Orissa and Rajasthan (1803-2003)
}

\author{
Wasudha Bhatt ${ }^{1}$ \\ Department of Sociology, University of Texas at Austin, \\ 1 University Station - A 1700, Austin, TX, USA 78712 \\ Email: wasudhabhatt@gmail.com
}

\begin{abstract}
A significant segment of internal migration in India at large, and in the states of Rajasthan and Orissa in particular, continues to be distress-led. Colossal collapse of rural employment generation, the economic setbacks at cultivation, and, the largely deficient employment opportunities in urban centres among others, are believed to be the driving force behind the rise of a more insecure type of movement now. Paradoxically however, this movement occurs in a world supplemented by a renewed belief in sanctioning equality of opportunity as a way of life, propagating fuller economic growth, and endorsing greater social cohesion (Aldridge 2001), across the sociopolitical spectrum. As a result, migratory processes and their subsequent impacts thereof, attains critical significance in the present times. It is in the above context that the proposed paper contextualizes migration debates within historiography, polity and economy of the states of Orissa and Rajasthan in India, and seeks to elucidate the formidable challenges it represents for the Indian social fabric.
\end{abstract}

\section{Keywords}

India; migration; Rajasthan; Orissa

\section{Introduction}

'A man and his wife and his brother who had gone to work in the brick-kilns of Andhra Pradesh were forced to return within a few months, weak from lack of food and with no money at all. The man fell ill and died in the train on the way back. The wife and brother were too terrified to remove the body off the train, as they knew they would be questioned by the police and feared

${ }^{1}$ Acknowledgement: The following study was undertaken as a part of the research project Study on Women and the NREGA. Research supported by 'The International Labour Organization' and located at 'Institute of Social Studies Trust', New Delhi. 
extortion by exploitative elements. The body had to be abandoned in the train. When Suna went to Hyderabad on the trail of local migrants to lodge a complaint about ill treatment and exploitative conditions, he was told by the Labour Commisioner's office that they had no jurisdiction over migrant workers from other States'. Period.

This tragic incident of an Oriya migrant family, narrated by Jagdish Suna, a young Oriya journalist to The Hindu, 13 May 2001 appeared in the national daily only a few years back. Profoundly reflecting the agonizing plight of poor migrants in India, this incident fervently reflects their easily expendable lives. More so, the situation of poor migrants in India has rapidly deteriorated since then. As a result, a substantial segment of internal migration in India at large, and within the states of Orissa and Rajasthan in particular, remains distressled. Colossal collapse of rural employment generation, the economic setbacks at cultivation, and, the largely deficient employment opportunities in urban centres among others, are believed to be the driving force behind the rise of a more insecure type of movement now. Ironically however, this movement is taking place in a world which is marked by a far more profound belief in endorsing equality of opportunity as a way of life, disseminating fuller economic growth, and promoting greater social cohesion (Aldridge 2001), across the socio-political divide.

As a result, migratory processes and their subsequent impacts thereof, attains critical significance in the present times. This study seeks to map the incidence and nature of migration in India at large, and the states of Orissa and Rajasthan in particular, by foregrounding it within the historical backdrop of migratory movements characterizing the respective regions. For a large country like India, the complexity of movement of population in different parts of the country helps in understanding the dynamics of the socioeconomic organization of the state. Moreover, it aims to gain a deeper insight into the migratory routes in Rajasthan and Orissa by studying the interactions between local economic development, decent work elements, ecological stresses and migration. By capturing the latest of the migrations in cases where persons have migrated more than once, this study thus would give a better picture of current migration scenario.

It is in the above context that the proposed paper seeks to undertake a theoretical and empirical analysis of the nature and pattern of migration in the states of Orissa and Rajasthan in India. The following paper is divided into six broad sections. This introduction defines my main objectives and the issues examined in the paper. The second section undertakes a conceptual analysis of 'distress migration', construed essentially as a 'means of survival', as opposed to being induced by better opportunities, when contextualized within the eco- 
nomic, political, and cultural landscape of India. The third section tries to broadly map out the nature and incidence of migration in India. Consequently, the two sections that follow try to analyze the pattern of migration by foregrounding it within the historiography, polity and economy of the states of Orissa and Rajasthan in India. Subsequently, tracing the evolution of migration since the nineteenth century, the segment tries to highlight the newer dimensions and the sharper transformative edge distress migration has acquired in postcolonial India. The conclusion summarizes the main arguments advanced. The paper finally ordaining migration as 'the' emergent vehicle for upward mobility within the current global hierarchy, crosscutting lines of class, caste, and gender, succinctly elucidates the formidable challenges it represents for the Indian social fabric.

\section{Stressors, Involuntary Mobility, And The Aftermath: A Theoretical Insight into Distress Migration}

In his article on 'migration' in the tenth volume of the International Encyclopedia of the Social Sciences, David L. Sills noted that 'Migration'-the word derives from the Latin migrare, thus referring to the change in residence involving movement between communities (Ritchey 1976). There is however considerable conceptual contestation in defining a migrant. Worker mobility may take different forms, which may however coexist. On one end of the political spectrum, the worker's place of residence and place of work may be different. While at the other end, workers may move permanently from their places of birth or usual place of residence, maintaining little or absolutely no contact with their place of origin. Complicating the situation further, people also move away for differing periods of time between these two extremes. However, most household surveys generally use a cut-off point to determine the usual place of residence, which in India stands to be six months. ${ }^{2}$

Nonetheless, exacerbating the complexity further, economic development, political stability, and the increasing integration of countries into the global political economy in regions all over the world has resulted in enhanced flows of capital, labour, raw materials and technology. These factors in turn have come to exercise a substantial influence on migration. Resultant, labour movements have quickened in response to disparities in income levels, wage levels and levels of human resource development, as workers cross borders to seek

\footnotetext{
${ }^{2}$ Nevertheless, such a cut-off point has no firm basis in migration patterns. For more details see: Sasikumar S.K. and Ravi Srivastava 2003 An overview of migration in India, its impacts and key issues, available from World Wide Web: http://www.livelihoods.org
} 
better conditions of work. In this context of enhanced migration activity, contemporary migration has come to have a significant impact on the well-being of migrants in particular, and, non-migrants, including the 'left behind' at large (Nguyen et al. 2006).

Contemporary theorists primarily attribute migration to the desire inherent in most men, to 'better' themselves in material respects, or enhance human wellbeing (Nguyen et al. 2006). It is thus that the surplus population of one part of the country drifts into another part, where the development of commerce and industry, or the possibility of procuring productive land still in a state of nature, calls for more hands to labour; thus resorting to migration. Herein, though the value of human welfare certainly seems to be intrinsic to humankind, yet, this represents just one side of the spectrum. Migration remains increasingly susceptible to a constraining effect not only structurally, with regard to the choices made available, or even culturally, but, also in the sense in which it may induce emotional and psychological distress (Nguyen et al. 2006). Herein, a number of factors play a critical role in sculpting the decision to migrate, which is counter-influenced by numerable other compulsions at work. "For the migrants, time presents itself differently in the host nation and the present is experienced as a double loss, of origin and of reality, a 'hyperreality', as it were" (Naficy 1991, 285-302). Further on, 'home is conceptualized in fluid terms as being neither here nor there... rather, itself, a hybrid, it is both here and there-an amalgam, a pastiche, a performance' (Rapport and Dawson 1998).

It is when viewed in the context above that images of migrants differ. On one side, migrants are perceived to be the rational economic agents, armed with the ability to judge differences in opportunities and rewards at home and the place of destination. However, the reverse image portrays them as victims of economic deprivation, political or social discrimination, and environmental degradation (Haan 2000). Here migration, rather than generated by opportunity and increased life chances, is understood to be encouraged largely as a psychological reaction to 'distress', provoked by the economic, social and political environs of the sending state.

Earlier migration theories explained this largely in dual terms of the push and the pull factors, i.e. the voluntarist perspective.

1) The early theories held that out-migration is highly susceptible to an increase as a result of various situations characterizing surplus labour. These could be attributed to scarcity of cultivated land, inequitable land distribution, low agricultural productivity, high population density, and the exclu- 
sive concentration of the rural economy on agriculture. These factor combinations thus created a 'push' (Deshingkar and Grimm 2004) which was more often than not encountered in fragile environs.

2) However, following the 1950s, the 'pull factor emerged as the inevitable consequence of the demand for labour, which was largely created by 'growing modern industrial complexes', and the intrinsic gap in rural and urban wages. ${ }^{3}$ Herein, the pull factor was also attributed to the desire inherent in most men for acquiring skills or gaining new experiences. Subsequently, voluntary migration of the poor for economic reasons was then re-determined by 'urbanisation and the spread of manufacturing'; with the inbuilt wage gap emerging as probably the most important pull.

However, Gallawery by introducing a conceptual distinction between voluntary and involuntary migration, shed a renewed light into the phenomenon of distress migration, as an extension of involuntary mobility. The essential characteristic of voluntary mobility is that potential migrants have the option of remaining in their present jobs. Here the decision to migrate involves the comparison of shadow wages offered in market areas. However, involuntary mobility results from workers being dismissed from their existing jobs because of poor performance, reorganisation, shifts in consumer demands, or other disabilities. Resultant, involuntary migrants would move to those areas in which job opportunities are more abundant numerically. He suggests that it is likely these workers are under great pressure to find work, have less market information and are less competitive than other workers. As a result, involuntary migrants would move to those areas in which job opportunities are more abundant numerically. ${ }^{4}$

Moore (1972) and Wolpert (1965) further suggest that migration herein is also motivated by an attempt to reduce the stressors and strains present in the residential environment (Lindquist, Lagory and Ritchey 1999, 691-709). Though changing residence is itself stressful, yet, distress migrants also face a series of stressors from their current, physical, psychological and social environments, as well as their previous circumstances and experiences. There are thus two aspects to the stress concept:

${ }^{3}$ There have since been many models and debates on what motivates people to migrate including theories of 'expected' as opposed to actual wage differentials.

${ }^{4}$ Gallawery here argues that there is good reason to expect a negative relation between the number of jobs available in an area and area earnings. Thus involuntary mobility can further confound the observed relation between mobility and earnings. For details, see: Ritchey P. Neal. 1976. Explanations of Migration. Annual Review of Sociology, Volume 2. 
- Stressors which are causative factors;

- And the stress reaction per se, which is the psychological and the physiological reaction of the organism, which results from its interaction with the stressor (Mirdal 1984, 9841003).

In view of that, an extensive part of internal migration in India at large, and from the states of Rajasthan and Orissa in particular, is 'distress-led'. It is induced by a colossal collapse of the economic difficulties marking cultivation, the availability of rural employment, and, the inadequate employment opportunities in towns to name a few. And this absolute desperation has led to a more insecure type of movement which is briskly on the rise. Infuriating the already miserable plight of these out-migrants, distress migration reeks of innumerable pitfalls. 'The difficulty of finding paid work, the sheer possibility of being duped, the exposure to criminality of various sorts, the problem of dealing with such basics as housing and sanitation, has been found to be particularly acute for such migrants, who are often constrained to simply living on the streets' (Ghosh 2005). As a consequence, it becomes all the more imperative for one to take on an in-depth analysis of the historiography, the causative factors, and the stress reaction per se; if one intends to obtain a far deeper insight into the pattern of distress-migration in these states.

\section{Mapping the Incidence and Nature of Migration in India}

\subsection{The Commencement of Migratory Streams in India: A Historical Insight}

Before the advent of agriculture, around 12,000 years ago, the Indian subcontinent was believed to be inhabited solely by hunter-gatherers, and the population density was extremely low (Dyson, Cassen and Visaria 2004, 16). Population movements into the subcontinent of India however started from the middle of the second millennium $\mathrm{BC}$, and continued into the nineteenth century. They subsequently altered the social structure and the political system of the region, and shaped its subsequent historical development. In his article on 'migration' in the first volume of The Oxford India Companion to Sociology and Social Anthropology 2003, Myron Weiner noted that the earliest known population flows was of the Aryans, who were a pastoral people migrating from Iran through Afghanistan to north-west India starting around $1500 \mathrm{BC}$, and eventually displacing the local Indus Valley Culture. Following which, in the fourth century BC, a thousand years later, Alexander the Great led his Greek army through Persia and Afghanistan into the lower Swat Valley of 
Pakistan, and then across the Indus to the Ganges. He was followed by the Sajthians, Arabs from Baghdad, Turkish invaders of Afghanistan and the Central Asian conquest of Northern India by Babur in the sixteenth century, and the subsequent consolidation of the Mughal rule under Akbar(ibid). Interestingly, a significant feature of these invasions was that the invaders governed from within India, and were subsequently absorbed into the Indian populace, as Indians. More so, as aptly stated by M.N. Srinivas, the Indian social order itself enabled many of the immigrant communities to become a part of the Indian Mosaic, without surrendering their community identity (ibid).

The existent literature on these early migration flows however primarily attributed migration to population expansion, new settlements, agro-ecological reasons and political conquests (Eaton 1984). But, it was the literature on patterns of migration during the British period and the abolition of slavery which followed, that brought new perspectives into light. If one accepts present scholarly interpretations of various literary sources, then slavery as forced appropriation of labour, skill or sexual gratification appears to have existed in varied forms from the pre-500 BCE period. While some scholars refer to interpretations that associate escalation or intensification or extension of slavery with rulers, elite, military commanders, political regimes professing Islam (beginning 7th century), as ideologically motivated. Nevertheless, it was the arrival of the British East India Company and the imposition of crown rule following the Indian Mutiny in 1857 along with the influence of the British anti-slavery society of William Wilberforce which eventually brought slavery and the slave markets to an end in India. Sir Henry Bartle Frere (who sat on the Viceroy's Council), estimated $8,000,000$ or 9,000,000 slaves in India in 1841. Further on, slavery was abolished in both Hindu and Muslim India by the Indian Slavery Act V. of 1843. This was followed by the provisions of the Indian Penal Code of 1861 which effectively abolished slavery in India by making the enslavement of human beings a criminal offense.

Following which, it was the abolition of slavery and the demand for replacement labour that played a large role in triggering Indian emigration abroad. Such emigrations were carried out normally through indenture, a form of contract labour, wherein a person would bind himself for a specified period of service, in return for payment of their passage. They would hence leave for the British, Dutch and French colonies to work in sugar plantations, and subsequently in the tea and rubber plantations of Southeast Asia (Tinker 1974).

Though a large part of this labour was procured through some form of organized mediation, yet, some portion of it did remain circulatory and retained robust links with the areas of origin. However post-migration, it 
acted as a beacon of hope for other migrants. With the result that the urban pockets of Kolkatta and Mumbai attracted numerous rural labourers. These laborers hailed largely from the underdeveloped and economically backward labour catchment areas of Bihar, Uttar Pradesh and Orissa in the east and Andhra Pradesh, Tamil Nadu, and parts of Kerala and Karnataka in the south(Joshi and Joshi 1976), (Alam, and Alikhan 1987) and (Sasikumar and Srivastava 2003).

Subsequently, migration only increased with the passage of time. Resultant, in the past few decades new patterns have emerged with regard to movement of labour in both developed and the developing world at large:

1) First, there have been shifts of the workforce towards the tertiary sector in both developed and developing countries.

2) Secondly, in developed countries, urban congestion and the growth of communication infrastructure have slowed down urbanisation.

3) Thirdly, in developing countries, the workforce shift towards the secondary/tertiary sector has been slow and has been dominated by an expansion of the informal' sector, which has grown over time (Sasikumar and Srivastava 2003).

While in 2001, India's population itself exceeded the 1 billion mark. 'At that time, $67.2 \%$ lived in rural areas and $32.8 \%$ in towns and cities. Between 1951 and 2001 , the proportion of the population living in urban areas rose from $17.3 \%$ to $32.8 \%$. Of the total workforce, $73.3 \%$ remained in rural areas, declining marginally from $77.7 \%$ in 1991 and $79.3 \%$ in 1981'(Sasikumar and Srivastava 2003). So much so, that S.K. Sasikumar and Ravi Srivastava propound that in some regions of India, as much as three out of four households include a migrant. ${ }^{5}$ In addition, permanent shifts of population and workforce co-exist with the 'circulatory' movement of populations between lagging and developed regions and between rural and urban sectors in India. Consequently, this labor force is mostly being absorbed in the unorganised sector of the economy (Sasikumar and Srivastava 2003). Evidently, the footprints of migration on individuals, households and regions are much larger than can be envisaged by the human mind. And with the passage of time migratory movements show little sign of abating with the rapidly unfolding development processes.

\footnotetext{
5 Nonetheless the influx of such population movements apart, Myron Weiner in his article on 'migration' in the first volume of The Oxford India Companion to Sociology and Social Anthropology 2003, maintains that presently only a small proportion of people in India live outside their place of birth or that of their spouses. He sights that between 1981 and 1991; only 13 million rural dwellers migrated to India's cities and towns, a little more than $2 \%$ of India's rural populace.
} 


\subsection{Contemporary Trends in Population Mobility}

When it comes to India, short distance migration predominates, with around $60 \%$ of migrants changing their residence within the district of enumeration, and over $20 \%$ within the state of enumeration, while the rest move across the state boundaries (Dyson, Cassen and Visaria 2004, 108). Herein, women too migrate over short distances following marriage, while the proportion of male lifetime migrants is less in most poor states and high in most developed regions. More so, inter-state migration reflects a similar trend: with developed states showing high inter-state immigration, while poor states, exhibiting low rates of total and male immigration (Sasikumar and Srivastava 2003).

Though migration statistics in the early 1990s suggested a decline in mobility, which prompted the inference that population mobility in India is low (Davis 1951) and (Kundu and Gupta 1996, 3391-98). Yet, recent evidence based on NSS figures for 1992-1993 and 1999-2000, and indirectly supported by the census, exhibit an increase in migration rates - from $24.7 \%$ to $26.6 \%$ over that period. In addition, as per the 2001 Census of India 2001 data, out of the total population of 1,028.6 million persons in India as at the 2001 Census, about 307 million (or 29.9\%) were reported as migrants born outside the village/ town of their enumeration. This is also exemplified by the rapidly rising figures of emigration for employment of people from: 1986-2005 in Figure 1.

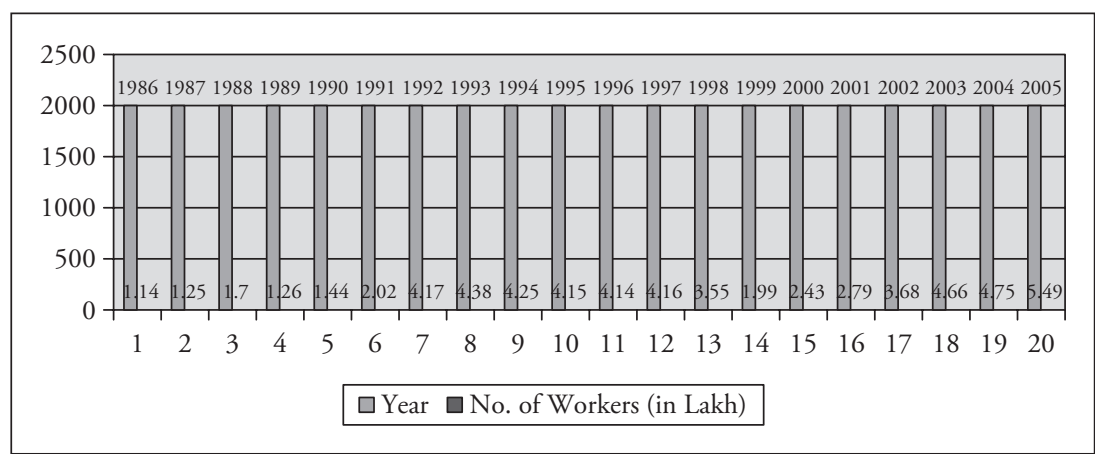

Adapted from statistics provided by Ministry of Labour and Employment, Govt. of India 2005, http://www.indiastats.com

\section{Figure 1}

Emigration for Employment in India 1986-2005 
Furthermore, the in-migrants in one state actually constituted the out-migrants from other states. Therefore, if one took into account the immigrants and outmigrants to and from all the states together, the net migrants as far as the country was concerned were only those who were born abroad (or 6.1 million) (Srivastava 1998, 41). Moreover, a comparison of the 2001 Census migration data with 1991 Census reflected high growth (32.9\%) in the number of total migrant by place of birth, which is much more than the natural growth of the population. Noticeably thus, the migration of population from across the boundary of the state rose sharply by $54.5 \%$ from about 27.2 million in 1991 to about 42.1 million in 2001 (Srivastava 1998, 41).

Moreover, Srivastava and Bhattacharya through their analysis of the NSS estimates from the 49th and 55th rounds on comparing the decadal migrant streams also reveal that:

1) a greater percentage of the urban migrant workers were from the non-agricultural sector (self-employed or regular employed);

2) a greater percentage of the male migrant workers were self-employed or in regular employment in 1999-00;

3 ) in the case of females, however, a larger percentage of decadal female migrant workers worked in 1999-00 as casual labourers (in the rural areas in agriculture) (Srivastava 1998, 41).

On the other hand, 'international migration' has always been numerically small compared to the size of India's population. However, out-migration since the 1960's is believed to have had the most profound effect on India's population, with the introduction of 'radically new ways of thinking and behaving, not least with respect to aspects of family and personal life'(Dyson, Cassen and Visaria 2004, 127). Table 1 which details distribution of annual labour outflows from India by destination also shows that annual labor outflows have increased substantially within 2001 to 2005.

Papola and Sharma however reasserting reality back into the frame propound that though figuratively India seems to be shinning, yet, it is only for a small minority of around $10 \%$, mostly consisting of the rich and higher middle class in the urban areas (Papola and Sharma 2004, 19-23). The labour market in the rural areas clearly reflects near zero elasticity of employment. More so, even if agricultural productivity witnesses a dramatic increase in the following decade, it will be unable to absorb much of rural labour considering the drastic fall in the contribution of agriculture to GDP, from ' 50 percent to 25 percent by the beginning of this decade' as asserted by Chandhoke (2005), owing to a slowing of output growth which has fallen below population growth. This has instead spurred an enormous rise in the streams of migrants 
Table 1

Distribution of Annual Labour Outflows from India by Destination (2001 to 2005)

\begin{tabular}{lccccc}
\hline \multicolumn{1}{c}{ Country } & 2001 & 2002 & 2003 & 2004 & 2005 \\
\hline United Arab Emirates & 53673 & 95034 & 143804 & 175262 & 194412 \\
Saudi Arabia & 78048 & 99453 & 121431 & 123522 & 99879 \\
Malaysia & 6131 & 10512 & 26898 & 31464 & 71041 \\
Qatar & 13829 & 12596 & 14251 & 16325 & 50222 \\
Oman & 30985 & 41209 & 36816 & 33275 & 40931 \\
Kuwait & 39751 & 4859 & 54434 & 52064 & 39124 \\
Bahrain & 16382 & 20807 & 24778 & 22980 & 30060 \\
Maldives & - & - & - & 3233 & 3423 \\
Mauritius & - & - & - & 3544 & 1965 \\
Jordan & - & - & - & 2576 & 1851 \\
Libya & 334 & 1339 & 2796 & 2303 & - \\
Others & 39865 & 83193 & 44044 & 10715 & 15945 \\
Total & 278664 & 367663 & 466456 & 474960 & 548853 \\
\hline
\end{tabular}

Source: Ministry of Labour and Employment, Govt. of India 2006, http://www. indiastats.com

in search of gainful employment. On the other hand, these migratory streams have also gained momentum as a result of rapid population growth and the breakdown of the jajmani system.

The Jajmani System constituted a significant component of the socioeconomic institution at the religious and at the economic plane of the preindustrial self-subsistent Indian village economy. A Jajman was one who employed a Brahmin for the performance of any solemn or religious ceremony. Religiously, it was an institutional arrangement that made the Brahman dependent for subsistence on the jajmans who comprised his clients. On the economic plane, this was marked by the exchange of products and services between the followers of various occupations within the framework of jajmani institution.

Consequently following the breakdown of the jajmani system in postindependent India, which was amplified by the decline of the caste hierarchy, emergence of contractual economic relationships, growth of better employment opportunities and transport following urbanization; migration is now accepted 
in rural areas as a 'fact of life' (Srinivas 2003). Moreover, the development of infrastructure and communications and expansion of the urban frontiers have further boosted labour movements, while simultaneously enlarging the social and mental space of villagers considerably.

These migratory streams nonetheless overlap with the innumerable workers who are employed in the informal economy, and constitute around 90 to 93 percent of the working populace. More so, 6 percent of the 10 percent of aggregate workers employed in the formal sector have jobs in the public sector. But even here:

(a) the low capacity of agriculture to absorb the work force and,

(b) job losses in the public sector have led to a decline in employment opportunities' as affirmed by Neera Chandhoke in her article on Democracy and WellBeing in India for the UNRISD Project on Social Policy and Democratization, May 2005.

Furthermore, Dyson and Visaria while forecasting the projected trends in urban growth and urbanization in India emphasize that urban bound movement-both rural-to-urban and urban-to-urban-will tend to increase. Nevertheless, they effectively bring home the point, by stating that 'India may well be alone among the world's major countries in still being predominantly rural in 2026' (Dyson, Cassen and Visaria 2004, 129).

\section{Migration in Orissa}

\subsection{A Historical Insight into Oriya Migration}

Orissa is a littoral state located on the east coast of India with a long coastline and a storehouse of mineral wealth. The state of Orissa carries along with it a history spanning a period of over 3000 years. 'The word Oriya is an anglicised version of Odia which itself is a modern name for the Odra or Udra tribes that inhabited the central belt of modern Orissa' (http://www.wikipedia.org and Encyclopedia Britannica 2008). And it is in alignment with this ancient republican tradition of Orissa that its history of migration also coexists. It was since the ancient and middle ages that Oriya merchants had formed trade links with other parts of the country. More so, the coastal region gave way to increased maritime trade which played a significant role in the development of Oriya civilization. This was followed by its extensive commercial, cultural, and political contacts with regions of Southeast Asia, particularly southern Burma, Malaysia and Indonesia. As a result, around the 7th century AD, the Kongoda Dynasty from central Orissa began migrating to Malaysia and Indonesia (Sahoo 2008). 
However, soon after the Second Anglo-Maratha War, in 1803 the British under the British East India Company occupied Orissa (Encyclopedia Britannica 2008). The British colonial rule over the state brought tremendous changes in the region, ${ }^{6}$ with the first British factories set up at Hariharpur in Orissa. Subsequently other factories were established in 'Balasore on the river Burabalanga and Pipil on the river Subarnarekha'. Following which, the two Orissa harbors comprised the bases for maritime trade. It had a severe impact on the social and economic life of the Oriya people. With time, the cottage industry shrunk, and numerous craft workers, especially weavers and dyers became bankrupt and unemployed, and were subjected to absolute poverty.

But, official historians like W.W. Hunter, and G. Toynbee turned a blind eye to the realities in their urge to rebuff the exploitative nature of the British Administration. Nevertheless, the mismanagement and failure of East India Company's provincial administration subsequently gave way to 'famines and rapid migration from villages to the developing urban centres within and outside Orissa. These were deliberately glossed over...' (Das 1976, 32-46). Consequently, the large number of unemployed workers created by the shrinking cottage industry, coupled with abject poverty, and extensive draughts and famines, initiated the first wave of migration from the state. As a result, large scale migration of Oriyas as indentured labour took place to work in East African countries on their plantations. Migration of unskilled labourers also took place to Malaya, Burma, Indonesia, and Caribbean countries (Sahoo 2008).

\subsection{A Review of Distress Migration in and from Orissa: The Interface between Poverty and Migration}

'Orissa has a total population of nearly 35 million people. In normal times, of these, $60 \%$ live below the poverty level. Almost $90 \%$ of the populations live in rural areas. More than $50 \%$ of the children below the age of 4 are suffering from malnutrition. Nearly $90 \%$ have access to safe water, but only $4 \%$ have sanitation. Health statistics are reported to be incomplete. However, under 5 mortality and maternal mortality is reported to be high and measles vaccination coverage around $60 \%$. Cholera and Malaria are endemic...' (Lárusdóttir 1999).

6 The first British factories were established at Hariharpur in Orissa. Subsequently other factories were established in Balasore on the river Burabalanga and Pipil on the river Subarnarekha. For details see: Ajaya Kumar Sahoo, Oriya Diaspora: A Brief History of Migration and Transnational Networks. Available from World Wide Web: http://www.blogs.fullorissa.com. 
The above statistics representing a sorry state of figures are from a report on Orissa by W.H.O. Sure enough; poverty and migration have always been interrelated in Orissa (Mahapatra 2005). An editorial in The Hindu, 13 May 2001 aptly stated, "be it long term unemployment, drought and crop failure, or displacement and chronic hunger, 'everything' in one of the poorest, yet resource rich, districts in India, is a struggle'". With income poverty being higher in Orissa than the rest of India, all data sources indicate that the gap in incomes and between Orissa, and the rest of India have been rapidly widening over the last twenty years. 'Whereas in 1980 per capita income in Orissa was $27 \%$ lower than in the rest of India, in 1997 it was $70 \%$ lower. The proportion of people below the poverty line is estimated at $47.13 \%$ compared with $26.1 \%$ in the whole of India' (Mahapatra 2005). Moreover, there are extensive disparities between the coastal and southern regions, which can be attributed to high concentration of Scheduled Tribe population in southern Orissa. $^{7}$

When contextualized in the above socio-economic scenario, long before the migrations swelled to an exodus, the National Commission on Rural Labour found (1991) there were 'more than 10 million circular migrants in the rural areas alone. These include an estimated 4.5 million inter-State migrants and six million intra-State migrants', as remarked by P. Sainath in an editorial for The Hindu, 15 March, 2004 aptly stated, However the NCRL report stands outdated, as it was in the 1990s that these numbers began to acquire gargantuan dimensions as never before. Lakhs of people began migrating to the other states to work as wage labourers, leading to a more permanent kind of migration wherein families often lost track of their loved ones, often never hearing again from them. ${ }^{8}$ Moreover, state-wise figures of Census of India 2001 detailing 1991 and 2001 population of Orissa, also shows a migration rate of 0.7 (per 100) in 1991-2001, and a population growth rate of 16.25

\footnotetext{
${ }^{7}$ What is more, the Scheduled Tribe population in coastal area is $7.2 \%$ as against $39.7 \%$ in the southern region. So, poverty ratio in coastal region is $64.0 \%$ as against $85.5 \%$ in the southern region. For details see: Devi Prasad Mahapatra, Labour Migration: A Shadow of Poverty in Orissa. Available from World Wide Web: http://EzineArticles.com/?expert=Devi_Prasad_Mahapatra.

${ }^{8}$ The Adivasis, Harijans and backward class villagers have always been struggling for their basic need (i.e. food). After the harvest, the villagers who are engaged in paddy field become jobless. Following which, without second thought, they have to leave their villages and their homes in search of 'work for food' and start their journey to the neighbor states for working in construction, in weaving, in hotels or as rickshaw- and cart pullers. 'This is not a new story; it is being repeated every year since 1965'. For details see: Devi Prasad Mahapatra, Labour Migration: A Shadow of Poverty in Orissa. Available from World Wide Web: http://EzineArticles.com/ ?expert=Devi_Prasad_Mahapatra.
} 
(1991-2001). On the other hand, Rajasthan exhibits a lesser migration rate of 0.6 (per 100) in 1991-2001, and a larger population growth rate of 28.41 (1991-2001).

Table 2

ORISSA. Number of persons migrated per 1000 persons of each category

\begin{tabular}{lcr}
\hline \multicolumn{1}{c}{ Period since migrated } & Female & Male \\
\hline 0 years rural persons & 5 & 3 \\
0 years urban persons & 12 & 12 \\
1-4 years rural persons & 56 & 27 \\
1-4 years urban persons & 82 & 89 \\
5-9 years rural persons & 64 & 12 \\
5-9 years urban persons & 73 & 53 \\
10 \& above rural persons & 275 & 27 \\
10 \& above urban persons & 256 & 143 \\
Total migrants & 823 & 366 \\
\hline
\end{tabular}

Adapted from the National Sample Survey 55th Round 1999-2000

However, migration has acquired a lethal edge following the devastation of agriculture in the last decade in Orissa. This has led to nil investment, collapse of the employment machinery, and spiraling of debt, thus shoving millions into the 'footloose army'. ' Unsurprisingly, seasonal migration has now become an important livelihood strategy for many Oriyas. Lakhs of poor tribal people and Dalits are migrating to distant towns in the State's coastal belt or outside to scrape a living (Das 2004). Table 2, along with Figure 2, clearly highlights an increasing number of migrants undertaking migration due to compulsions induced by work and marriage. Moreover, this is further marked by a predominance of women migrants over men.

Depleting the already bleak scenario, the middleman and the labour contractor better known as 'sardar', who organize the laborers into small groups, and send them to different destinations, has emerged as the new set of tormentors when the rural credit folded in early nineties. With the rich industrialists, brick-kilns owners, and the road contractors savoring the cheap and skilled labour supplied by the 'sardar', migration of people has now

\footnotetext{
9 The expression 'footloose army' is borrowed from: P. Sainath, The Millions Who Cannot Vote, Available from World Wide Web: http://www.hindu.com/2004.
} 


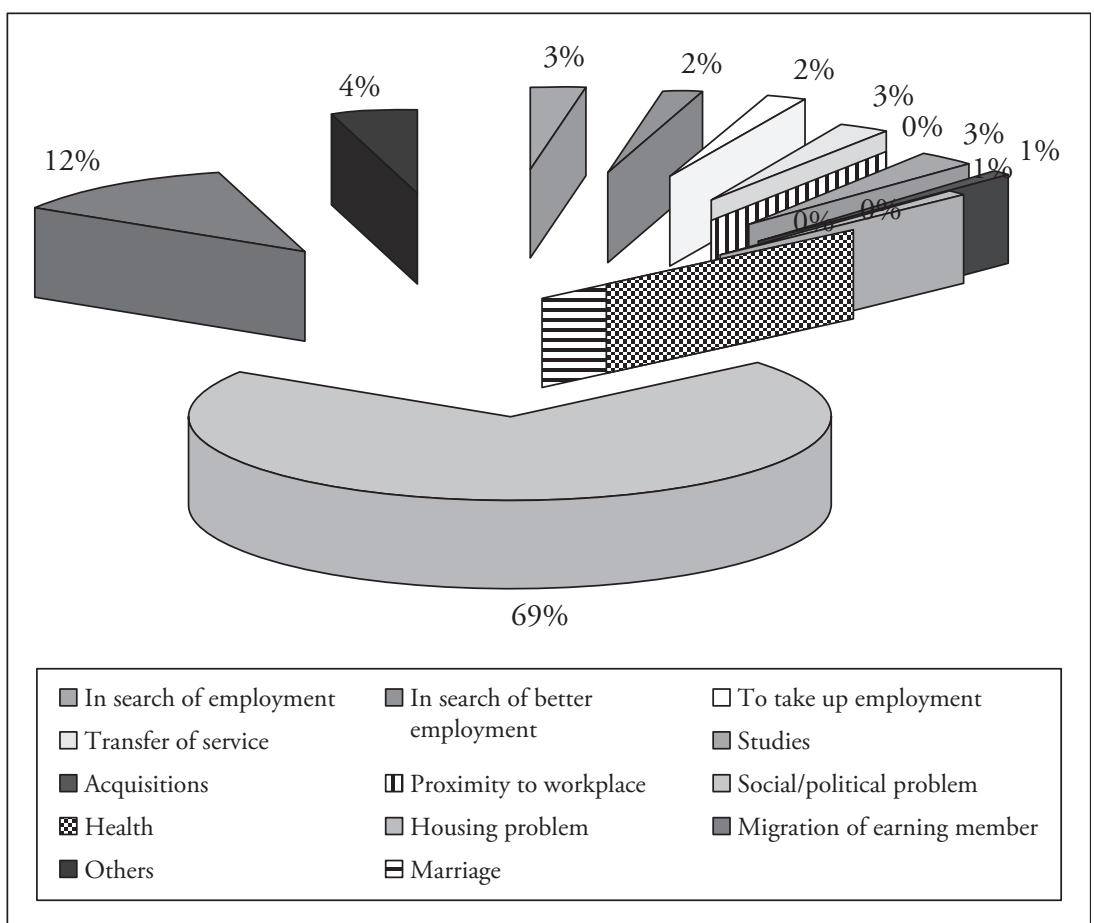

Adapted from the National Sample Survey 55th Round 1999-2000

Figure 2

Reasons for migration in Orissa 1999-2000

become a big business running into crores of rupees in this no-industrial belt. Consequently, this has led to a manifold multiplication of the miserable plight of these gullible laboureres, with many of the migrants having fewer guarantees, and lacking in local support systems while they are away (http://www. ex.ac.uk/imm). More so, since the deals are struck in Orissa, the labour machinery of a host state can't undertake any action against the contractors (Hardikar 2004). Though, occasionally at a vulnerable time, the sardar do come to the rescue of the poor laborers by offering a loan, for anything from Rs. 5,000 to 20, 000 (Mahapatra 2005), this instead becomes a gateway for the commencement of the migration cycle and for the repayment of debt by these migrant laborers.

Consequently, in recent times, out-migration from Orissa neither awaits any 'natural' calamity to occur, nor does it cater distinctly towards humanizing the lot of the migrant families (http://www.labourfile.org). Hence, the sea- 
sonal migration of people to neighboring states, particularly to Andhra Pradesh, is a standard phenomenon especially during seasons when work is scarce locally (Sainath 2004). Most of the Oriya labourers known as 'Pathuria', migrate to Andhra Pradesh usually from November to May, to work in brick kiln. 'These pathurias are working in brick kilns with a rate of payment about Rs 80 for 1,000 bricks made. They work for 12 to 15 hours, sometimes 18 hours a day to get the wage (around Rs. 70 per day) more than the home state. The minimum wage for daily labour in Orissa is little more than Rs 50. The final settlement is made only when they are ready to leave that place'. ${ }^{10}$ This final settlement also includes deduction of all the payment such as food expenses or any other expenditure. Consequently, sometimes the return journey traverses into the last journey for many of these migrant labourers. Moreover, making matters worse, those who cannot migrate also suffer. They battle hunger, succumb to starvation, and when pushed to the wall they sell their children to survive. Whereas various committees arriving in convoys to enquire, and investigate only serve to alienate them further from the State (Das 2005).

\section{Migration In Rajasthan}

\subsection{Rajasthan: The Traditional Patterns of Migration in the State}

Rajasthan is the largest state of the Republic of India in terms of area encompassing most of the large, inhospitable Great Indian Desert (Thar Desert), which has an edge paralleling the Sutlej-Indus river valley along its border with Pakistan. The migration of men and livestock between complementary ecological zones has been a traditional way of life in Rajasthan ('land of kings'), and a frequent feature in the arid and semi-arid regions of the state (Kavoori 2002). This can be contextualized within the wavering agricultural practice and depleted agricultural yield characteristic of the desert region, which has given way to 'pastoralism' for distributing the production risk. As a result, agriculture of large tracts of non-arable and marginal land, coupled with the use of seasonally fallow rain fed crop tracts as pastures forms, combines to

10 When we talk about the law for migration issue, the only law, the Interstate Migrant Workman Act, 1979, formulated with particular attention to western Orissa, was applicable only to people who crossed state boundaries. Movements within the state did not fall within its purview. Its emphasis is on regulation of movement, not on welfare and security. And it is almost impossible to apply the law in favour of individuals. More so, there is still no state machinery to follow up on names and addresses, even if a worker is able to report them. For details available at World Wide Web: http://EzineArticles.com/?expert=Devi_Prasad_Mahapatra. 
support the region's rural economy. Subsequently, the process of migration has in fact emerged as an integral and far more reliable part of the region's agrarian economy.

Moreover, inheriting a diverse physiography, the state is replete with a nonnucleated and dispersed pattern of settlement (Rajasthan Human Development Report, 2002). Herein, it is characterized by a highly skewed class-size distribution of landholdings: ' 50 percent of total numbers of landholdings are marginal or small, measuring less than two hectares in size. These cover only 10 percent of total area under cultivation'(Rajasthan Human Development Report, 2002). In addition, the state exhibits tremendous regional and social variations, which mediate access to all resources, and are intricately linked with its ecological plane, while informing the emergent migration patterns.

Herein, one can sight the example of the pastoral region to the west of the Aravalli Range which is absolutely a separate ecosystem from the rest of the Rajasthan (Jagori 2001). It stands in complete contrast when compared to southern Rajasthan which abounds with a history of bonded labour and exploitation within the tribal institutional framework (Jagori 2001). Migratory processes in the state further acquire pace, when foregrounded within the existing social fabric of the region. Here nomadic tribes who have been the traditional migrants, have had no citizen's rights, no visibility in the Census, and villages have often been unwilling to let them in and occupy revenue lands. And hence the journey for some of these social outcastes always remains devoid of any final destination. As a result, these mechanisms of caste accommodations and networks built over generations, provoked by the fragile ecosystem and the arid environment, have largely induced migratory processes often taking place in clusters and networks (Jagori 2001).

Another important aspect of this 'transhumance migration' is pastoral migration, which constitutes an essential part of the ecosystem of Rajasthan. Pastoral groups usually migrate in huge groups, of hundreds or thousands, with cattle and all belongings. With the acquisition of cattle accomplishing considerable significance in the lives of the landless and marginal land holding population of the desert village, sheep husbandry has emerged as a significant means of livelihood for these groups (Kavoori 2002). Moreover, even the dependence of the marginal groups on migratory sheep husbandry extends far beyond those keeping flocks, to those, 'that provide support services, such as roving bands of sheep shearers, buyers of sick and tired animals and mobile wool merchants'.

In a normal year, migration begins sometime in October, with the monsoons heralding the return of the flock to their home tracts. The direction of migra- 
tion is usually towards areas bordering Uttar Pradesh, Madhya Pradesh and Gujarat (Kavoori 2002). 'Estimates are that about $45 \%$ of the total sheep flocks in the state migrate. Over 2 lakh families are considered to be dependent on migratory sheep husbandry for their livelihood though some argue that this figure might well be a conservative estimate'(Kavoori 2002). Sirohi, Barmer, Bikaner, Churu, Jaisalmer, Jalore, Nagaur, Pali, and to some extent, Ajmer are some of the districts from which migration mainly takes place in the state. ${ }^{11}$

\subsection{An Overview of Distress Migration in and from Rajasthan: The Drought and the Mutation of the Traditional Migratory Pattern into Distress}

In the recent times, recurrent monsoon irregularities have resulted in extended periods of drought that periodically threaten the well-being of livestock and human populace inhabiting the state, and have simultaneously wreaked havoc on the traditional pattern of migration of labour. Following which, the last three years of the recurrent drought in Rajasthan and in the neighbouring States as well have been devastating, affecting over 3.3 crores of the population. With vanishing livelihood many villages are suffering from acute crises and severe malnutrition. All the more, with almost every family owning livestock, cattle have started perishing, due to the paucity of green fodder. Even the government admits that the immediate fallout of the drought has led to a burgeoning rate of unemployment, 'especially among the landless agricultural labourers, small and marginal farmers, families below poverty line (BPL) and rural artisans' (Rajalakshmi 2003) as well.

Meanwhile, drought-affected people have paid an enormous price for this stalemate. In most of the villages, the number of persons seeking employment on relief works far exceeds the number of jobs available. 'According to a recent survey of 105 hamlets in drought-affected areas of Rajasthan, in April-May this year eight persons were seeking employment on relief works for every person actually employed'. ${ }^{12}$ Moreover, women of all ages constitute a sizeable

${ }^{11}$ As a result seasonal labour migration of bhil adivasis (the rural tribal communities of the borderlands of south Rajasthan, and eastern Gujarat) in western India for casual work in urban construction and related industries has also increased. For details see: Mosse, Gupta, and Shah, On the Margins in the City Adivasi Seasonal Labour Migration in Western India, 2005. Available from World Wide Web: http://www.epw.org.in.

12 The pitiable plight of these drought affected people seeking employment in relief works was further worsened with the introduction of draconian ceilings on the numbers employed on relief works in 200. This was a blatant violation of Rajasthan's famine code, which clearly stipulated (Clause 75) that every person who comes for relief work shall be provided with work. For more details see: Jean Dreze, 2001 From food-for-work to fight-for-work. Available from World Wide Web: http://www.hinduonnet.com. 
majority of any labour force engaged in relief work. Following which, the young children accompanying them are also exposed to high-risk conditions during the day. Figure 3, which details the various reasons for migration in Rajasthan shows that as many as $41 \%$ of the people have reported to migrate with their complete households, with over 30\% sighting work and employment as the second important reason. More so, as exemplified by Table 3, women outnumber men in migration, something which is similar to Orissa. ${ }^{13}$ If not anything else, these figures are a blatant confirmation of the intense misery infecting the migrants in the state.

\section{Table 3}

RAJASTHAN. Number of persons migrated per 1000 persons of each category

\begin{tabular}{lcr}
\hline \multicolumn{1}{c}{ Period since migrated } & Female & Male \\
\hline 0 years rural persons & 9 & 4 \\
0 years urban persons & 20 & 13 \\
1-4 years rural persons & 84 & 17 \\
1-4 years urban persons & 107 & 77 \\
5-9 years rural persons & 78 & 11 \\
5-9 years urban persons & 92 & 55 \\
10 \& above rural persons & 352 & 32 \\
10 \& above urban persons & 262 & 103 \\
Total migrants & 1004 & 312 \\
\hline
\end{tabular}

Adapted from the National Sample Survey 55th Round 1999-2000

Subsequently, the existent high levels of ecological stress upon land, water and forests resources of the State have been multiplied by encroachment from the more powerful interest groups. ${ }^{14}$ The precarious situation of these migrants is

\footnotetext{
${ }^{13}$ See TABLE 2.

${ }^{14}$ The influence of these interest groups is not limited to the economic spectrum only. It extends into the social domain and critical sectors of education as well. As a result of which the present educational system is largely enforcing the basic socio-economic structure with its 'social hierarchy and flagrant inequalities'. With the expansion taking place in laissez faire style largely, and denied of purposeful interventions, education is confined to large central villages. For details see: Mohd Akhtar Husain. 1983. Access to Schooling in Rural Areas: A Case of Selected Villages of Rajasthan, Social Scientist, Vol. 11, No. 7. pp. 50-57.
} 


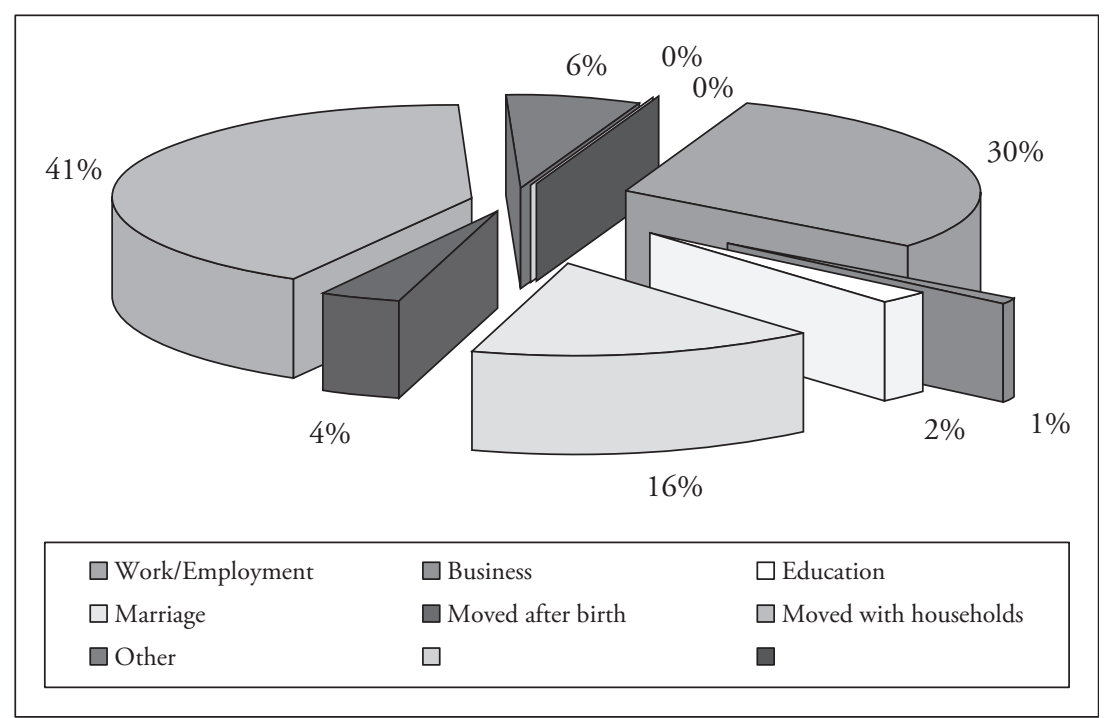

Adapted from the Census of India 2001

Figure 3

Reasons for migration in Rajasthan 2001

further compounded by the increased levels of urban poverty, as compared to rural poverty levels. This is coupled with the high rates of growth of urban population (40 percent 1981-91), in contrast with that of rural population (22.9 percent) settlement (Rajasthan Human Development Report, 2002) leading to urban congestion as the cost of migration to be borne by the society at large. These constrictions are further compounded by 'bureaucratic inertia, infrastructural bottlenecks, lack of communication between Ministries', and the 'blame game' between the Central and State Governments. With constructive efforts to resolve these differences being few, the state governments complain of insufficient food allotments from the Centre. The Centre, for its part, holds the State Governments accountable for failing to make full use of their existing allotments (Dreze 2001).

Moreover, the agonizing plight of these migrants is reflected in their willingness to accept a lower wage in the village and their compliance to bear the costs of migration along with the hostile and exploitative environs postmigration (Khera 2006). To begin with, migration traverses into an expensive journey, with massive transport costs, uncertain earnings, health hazards, and increased costs of living in urban areas coupled with poor living conditions. 
Subsequently, migration leads to a complete upheaval and emotional turmoil in the social life, which is true both in the case of migration of men alone and of entire families as well. However the situation worsens manifold with migration of entire families, with children having to be removed from schools into precarious environments, and women becoming far more susceptible to sexual exploitation. This has happened in the case of carpet industries which were shut down for use of child labor, and have since relocated to Rajasthan and started employing women (Khera 2006).

The situation above represents the plight of migrants in the rural areas. However, the cities have not been far removed from the adverse multiplier effect migration has had on the urban centers. Even here, one can witness tremendous spurt in begging, increased number of rikshaw pullers, women in prostitution, swelling suburbs and slum settlements and labor in 'choktis.' 'Chokti is the local name given to particular places in the city where labourers, most of whom have migrated from the rural areas, assemble in the early morning to provide their services to contractors who come looking for casual, daily wage labour in their worksites'(Jagori 2001). It's an arrangement by mutual consent catering to the needs of both the parties. 'Where there were once 100 people in one place, there are now 250-300 people in the same place. Often the whole family is there to provide for labour'. Nevertheless, these choktis are also castigated by the falling work available, and the resurgence of the mafia builders who are now playing a predominant role in exploiting these workers (Jagori 2001).

As a result, in Orissa and Rajasthan, the migration component remains high but net domestic product (NDP) levels are still abysmally low. Recent official statistics illustrate that rural-rural migration continues to dominate, accounting for roughly 62\% of all movements in 1999-00 (Srivastava and Bhattacharyya 2003). Workers from backward states like Orissa and Rajasthan regularly travel to the developed green revolution states of Maharashtra, Punjab and Gujrat for the transplant and harvesting season.

In addition there are plenty of other examples, many of which remain undocumented. Project staff and local government officials involved in rural livelihood programmes frequently cite the rising incidence of seasonal migration. Bolangir a very poor and drought-prone district in Orissa is an arresting example. A projected 60,000 people migrated out during the2001 drought (Wandshcneider and Mishra 2003) alone and current informal estimates are in the region of 300,000. 'Research by Mosse et al. (1997) of the first phase of the DFID funded Western India Rainfed Farming Project (Madhya Pradesh, Gujarat and Rajasthan) notes that $80 \%$ of cash income in project villages was derived from migration. Even where remittances are irregular and small they 
may play an important role in reducing vulnerability and improving food security' (Deshingkar 2006).

What is more, with the volume of migrants into cities increasing phenomenally, the wave of seasonal migration has also eclipsed women, who are now compelled to go into cities looking for wage labour. Herein exists a unique phenomenon, that of seasonal migration of young tribal adolescent girls to work primarily in the cotton picking fields of Gujrat or to Udaipur city, and also, other sectors such as the tobacco industries, oil pressing mills, and for cleaning out-machinery during the dry months (Jagori 2001). However, in the year 2001, an interesting episode was captured in print, which has been oft re-telecasted in the lives of these migrants. These girls returned empty-handed chiefly because drought conditions and water scarcity had affected construction work and the availability of employment. Ironically, 'It is said that in Gujarat the owners of cotton fields sent them back saying that they should ask the Rajasthan government to provide them work' (Rajalakshmi 2001).

\section{Conclusion}

As a result, labour movements have quickened in response to disparities in income levels, wage levels and levels of human resource development, as workers cross borders to seek better conditions of work, thus motivated by an attempt to reduce the stressors and strains present in the residential environment as suggested by Moore (1972) and Wolpert (1965) earlier. Migration, especially circular migration, will continue in all likelihood either until the breach between different regions tapers down or until the unsustainable environs in the sending area drive out population's altogether. Consequently, labour-intensive manufacturing, construction and urban services in the developed Western and northern states of India such as Punjab, Maharashtra and Gujarat now constitute major destinations for inter-state migrants from the poorer and drought-prone areas like that of Orissa. This is evident in the powerlooms and diamond polishing businesses in Gujarat which attract innumerable migrants from Orissa (Deshingkar 2006). The problem gets accentuated with the extensive rural-urban movement of people encouraged largely as a psychological reaction to 'distress' (Mirdal 1984, 9841003) within states with acute regional inequalities such as in Rajasthan. For instance, there are great numbers of migrant workers in sand mining and stone quarrying in Rajasthan.

What is more, one can witness a swap from rural-rural to rural-urban circular migration which is occurring in areas where agricultural employment is 
dwindling and industrial jobs are being created either at the same destinations or elsewhere. This is evident in a study of tribal migration from Orissa, which demonstrates that migration has altered from the rural-rural migration of the pre-1980s to rural destinations in Bihar and West Bengal, to rural-urban migration to distant metropolises of Delhi, Kolkata and Mumbai (Jha 2005). While it cannot be claimed for sure that these studies show a definite trend, yet it is probable that urban and manufacturing opportunities will acquire more appeal for internal migrants.

It is also imperative to realize that agriculture alone cannot sustain rural livelihoods, following the decline in rate of job creation and real wage increases in agriculture in India. This can be attributed to the deteriorating land-person ratios, crashing commodity prices post-market liberalization, water scarcity, and unrelenting drought. As much as two-thirds of the arable area in India remains semiarid and drought prone and most of these areas exhibit increased rates of seasonal migration as witnessed in the Bolangir district in Orissa marked by low levels of agricultural production and persistently high levels of poverty, and Rajasthan (Mosse et al. 1997) which revealed that 65 per cent of households included migrants (Deshingkar 2006).

Inevitably, administering migration for maximizing the gains and reducing risks and costs necessitates effective partnerships between the private sector organizations, government, and the civil society. It's essential that policy recognizes that rural livelihoods in marginal areas are robustly linked to urban development and manufacturing and resources need to be re-allocated accordingly. Herein, it is important for state governments to collaborate with each other and formulate adaptable and pro-poor social services which can be accessed by migrants. Likewise, strengthening of education and skills would be central in aiding the poor in breaking away from tyrannical and low paying jobs.

There are no easy answers and definite interventions ought to be created through learning and piloting for poverty reduction and development in Rajasthan and Orissa. Policies should also intend to relieve the sufferings of migrants and aid a flexible labour force for evenly distributing benefits of growth in the short term. But over the long term one must develop human capabilities so migrants can diverge into more remunerative options and migration provoked by distress does not degenerate into further trauma. 


\section{References}

Tirpude College of Social Work, Civil Lines, Sadar. 2004. A Research Study On Migrant Tribal Women Girls in Ten Cities: A Study of Their Socio-Cultural and Economic Reference to Social Intervention. New Delhi. Available from World Wide Web: http://planningcommission.nic. in/reports/sereport/ser/stdy_mgrwmn.pdf.

Arizpe, Lourdes. 1981. "Relay Migration and the Survival of the Peasant Household,” In (Ed.) Jorge Balan, Why People Move. Paris: UNESCO Press.

Alam, S.M. and F. Alikhan. 1987. Perspectives on Urbanization and Migration: India and USSR. Delhi: Allied Publishers.

Aldridge, Stephen. 2001. Social Mobility: A Discussion Paper. Available from World Wide Web: http://www.strategy.gov.uk/downloads/files/socialmobility.pdf.

Chandhoke, Neera. 2005. Democracy and Well Being in India. Draft Working Document for the UNRISD Project on Social Policy and Democratization.

Census of India. 2001. Government of India. Available from World Wide Web: http://www. censusindia.gov.in.

The Sustainable Coastal Livelihoods (SCL) Project. 2000. Coastal Migration and Mobility. Available from World Wide Web: http://www.ex.ac.uk/imm.

Connell, J.B., Das Gupta, Laish Ley and M. Lipton. 1976. Migration from Rural Areas: The Evidence from Village Studies. New Delhi: Oxford University Press.

Courchene T.J. 1970. Interprovincial migration and economic adjustment. Can. J. Econ.3.

Lárusdóttir, Jóhanna. 1999. Cyclones in Orissa India. Available from World Wide Web: http:// www.OrissalWHO Orissa Report.htm.

Das, Binod S. 1976. Orissa's Economy in the Nineteenth Century, Social Scientist. Vol. 4, No. 11.

Das, Prafulla. 2004. "Backwardness and a mood of Cynicism: Cover Story," Frontline. Vol. 21, Issue 09.

—. 2005. "Eloquent images of Struggle," The Hindu. Available from World Wide Web: http://www.hinduonnet.com.

Davis, K. 1951. The Population of India and Pakistan. New Jersey: Princeton University Press.

Deshingkar, P. and Sven Grimm. 2004. Voluntary Internal Migration: an update. Available from World Wide Web: http://www.odi.org.uk/ Distress: A way of life in Kalahandi. 2001. The Hindu. Available from World Wide Web: http://www.hinduonnet.com.

Dreze, Jean. 2001. "From food-for-work to fight-for-work," The Hindu. Available from World Wide Web: http://www.hinduonnet.com.

—. 2001 “Starving the poor - II," The Hindu. Available from World Wide Web: http://www. hinduonnet.com.

Eaton R. 1984. The Rise of Islam and Bengal Frontier. Delhi: Oxford University Press.

Ellis, F. "Household Strategies and Rural Livelihood Diversification," Journal of Development Studies 35(1): 1-38.

Fawcett, J.T., S. Khoo, \& P.C. Smith. 1984. Women in the Cities of Asia: Migration and Urban Adaptation. Colorado: Westview Press.

From the fields: Migration has Struck Deep Roots. Available from World Wide Web: http://www. labourfile.org/ArticleMore1.aspx?Nid=546.

Gender Dimensions in Rural-Urban Migration in India: Policy Imperatives. Available from World Wide Web: http://www.iussp2005.princeton.edu.

Ghosh, J. 2005. "Migration and public policy,” Frontline. Volume 22 - Issue 10.

Haan A.D. 2000. "Migrants, Livelihoods, and Rights: The Relevance of Migration in Development Policies," Social Development. Working Paper No. 4.

Hardikar, Iaideep. 2004. Orissa's labour industry. Available from World Wide Web: http://www. OrissalIndia Together. 
Baneria, L. (ed). 1982. Women and Development. Geneva: Praeger for ILO.

Husain, Mohd Akhtar. 1983. "Access to Schooling in Rural Areas: A Case of Selected Villages of Rajasthan," Social Scientist. Vol. 11, No. 7.

Jha, Vikas. 2005. "A New Story of Exploitation Migration of Orissa's Tribal Women,” Economic and Political Weekly.

Jolly, S. and Hazel Reeves. 2005. Gender and Migration: Overview Report. BRIDGE, Institute of Development Studies: University of Sussex.

Joshi, V. and H. Joshi. 1976. Surplus Labour and the City: A Study of Bombay, Delhi: Oxford University Press.

Kamp, J.V. 1971. "Migration flows, their Determinants, and the Effects of Return Migration," Journal of Political Economy, 79.

Kavoori, Purnendu. Transhumance and Pastoralism, Chapter III - Sources of Livelihoods in Rajasthan. Available from World Wide Web: http://www.undp.org.in

Khera, Reetika. 2006. Employment guarantee and migration. Available from World Wide Web: http://www.hinduonnet.com.

Kundu, A. and S. Gupta. 1996. "Migration, urbanization and regional inequality," Economic and Political Weekly.

Lindquist Christine H., Mark Lagory, and Ferris J. Ritchey. 1999. "The Myth of the Migrant Homeless: An Exploration of the Psychosocial Consequences of Migration," Sociological Perspectives. Vol. 42, No. 4.

Orissa. 2008. In Encyclopadia Britannica. Retrieved December 24, 2008, from Encyclopædia Britannica Online: http://www.britannica.com.

Osella, Filippo, and Katy Gardner Ed. 2004. Migration, Modernity and Social Transformation in South Asia. New Delhi: Sage Publications.

Mahapatra, Devi Prasad. 2005. Labour Migration: A Shadow of Poverty in Orissa. Available from World Wide Web: http://www.EzineArticles.com.

Jagori. 2001. Migration, Trafficking and Sites of Work: Rights and Vulnerabilities, A pilot study: Report of initial findings in Rajasthan and Gujrat. Available from World Wide Web: http:// www.jagori.org.

Mirdal, G.M. 1984. Stress and Distress in Migration: Problems and Resources of Turkish Women in Denmark. International Migration Review. Vol. 18, No. 4.

Mosse, D., Sanjeev Gupta, and Vidya Shah. 2005. "On the Margins in the City Adivasi Seasonal Labour Migration in Western India," Economic and Political Weekly.

Mukherji, S. 2001. "Internal Migration - Social Processes and National Patterns Low Quality Migration in India: the Phenomena of Distressed Migration and Acute Urban Decay". 24th IUSSP Conference, Salvador, Brazil, Session 80.

National Institute of Urban Affairs. 1981. Mechanisms of Underdevelopment, Labour Migration and Planning Strategies in India. Calcutta: Prajna and, 1988. State of India's Urbanization. National Institute of Urban Affairs (NIUA).New Delhi.

Nguyen L., Brenda S.A. Yeoh and Mika Toyota. 2006. "Migration and the well-being of the 'left behind' in Asia.," Asian Population Studies. Vol. 2, No. 1.

NSSO 55th Round Report. Government of India.

Papola, T.S. and A.N. Sharma. 2004. "Labour: down and out?" Seminar.

Rajalakshmi,T.K. 2003. "From bad to worse in Rajasthan," Frontline. Volume 20 - Issue 09.

—. 2001 Rajasthan's Thirst. Frontline. Volume 18 - Issue 06.

—. 2002 Rajasthan Human Development Report. Rajasthan.

Rao, M.S.A., (Ed). 1986. Studies in Differentiation: Internal and International Migration in India, New Delhi: Manohar Publications.

Rapport, N. and Andrew Dawson. 1998. Migrants of Identity. New York: Berg.

Ritchey, P. Neal. 1976. Explanations of migration. Annual Review of Sociology. Vol. 2. 
Sahoo, A.K. Oriya Diaspora: A Brief History of Migration and TransnationalNetworks. Available from World Wide Web: http://www.geocities.com/husociology/oriya.htm

Sainath, P. 2004. The Millions Who Cannot Vote. Available from World Wide Web: http://www. hinduonnet.com.

Sasikumar, S.K. and Ravi Srivastava. An overview of migration in India, its impacts and key issues. Available from World Wide Web: http://www.livelihoods.org.

Saxena, N.C. 2004. "Improving Service Delivery," Seminar.

Sen, Amartya. 2001. "Many Faces of Gender Inequality," Frontline. Vol. 18 No. 22.

Shanthi, K. 1993. "Female Mobility and Gender Dimensions in Labour Migration. Institute for Economic Development," Discussion Paper, Series No 32., Boston University, Boston.

Srinivas, M.N. 2003. "An Obituary on Caste as a System.” Available from World Wide Web: http://www.epw.org.in.

Srivastava R.S. 1998. "Migration and the Labour Market in India," Indian Journal of Labour Economics. 41(4).

Thapan, M., Ed. 2005. Woman and Migration in Asia: Transnational migration and the Politics of Identity. New Delhi: Sage publications.

- 2002. The ground realities, A first-round study of the drought situation in some of the badly affected States, in the north and the west: Rajasthan, Gujarat, Punjab, Haryana, Uttar Pradesh, Madhya Pradesh and Maharashtra, Frontline, Volume 19 - Issue 17.

Tinker, H. 1974. A New System of Slavery: The Export of Indian Labour Overseas 1830-1920, London: Oxford University Press.

Unni, J. and Uma Rani. "Gender, informality and Poverty." Seminar. Available from World Wide Web: http://www.india-seminar.com.

United Nations. 2005. 2004 "World Survey on the Role of Women in Development: Women and International Migration” Available from World Wide Web: http://www.un.org/ womenwatch. 


\section{MAPS:}
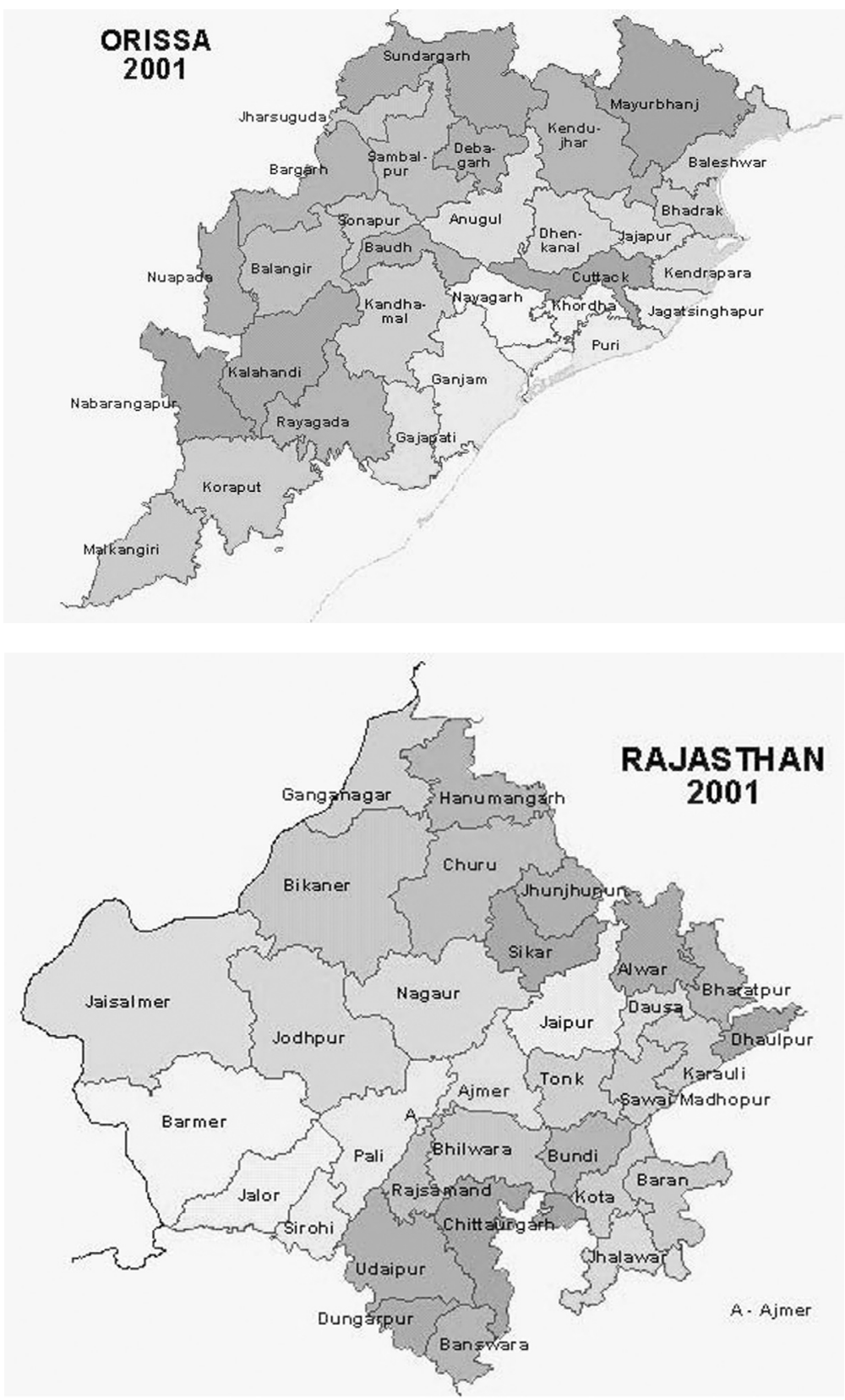

Adapted from the Census of India 2001 